\title{
Insulin increases the density of potassium channels in white adipocytes: possible role in adipogenesis
}

\author{
M P Ramírez-Ponce, J C Mateos and J A Bellido \\ Departamento de Fisiología Médica y Biofísica, Facultad de Medicina, Avenida Sánchez Pizjuán 4, 41009 Sevilla, Spain \\ (Requests for offprints should be addressed to M P Ramírez-Ponce; Email: pponce@us.es)
}

\begin{abstract}
We studied the potassium currents in white adipocytes obtained by culturing preadipocytes from rat epididymal tissue, both with insulin $\left(\mathrm{WA}_{\mathrm{i}}\right)$ and without insulin $\left(\mathrm{WA}_{\mathrm{o}}\right)$, in order to test the role of insulin in the development of voltage-gated potassium channels $\left(\mathrm{K}_{\mathrm{v}}\right)$ during adipogenesis. Occasionally, very small potassium currents $\left(\mathrm{I}_{\mathrm{K}, \mathrm{V}}\right)$ were present in preadipocytes; however these currents were measured in all differentiated cells (adipocytes). $\mathrm{WA}_{\mathrm{i}}$ exhibited greater macroscopic potassium currents than $\mathrm{WA}_{\mathrm{o}}$ with no apparent differences in kinetics or voltage dependence. The current density $\left(\mathrm{pA} / \mu \mathrm{m}^{2}\right)$ calculated in $\mathrm{WA}_{\mathrm{i}}$ was higher than in $\mathrm{WA}_{\mathrm{o}}$. Currents were blocked by millimolar concentrations of tetrethylamonium (TEA). The effect of insulin on adipogenesis, both with
\end{abstract}

and without TEA, was analysed. Four days without insulin and three days with insulin were necessary to increase the total number of cells in culture by $2 \cdot 5$-fold. Insulin increased the number of differentiated cells by $73 \cdot 5 \%$. Cell proliferation and differentiation were inhibited by TEA. Proliferation was affected only by high concentration of TEA. Inhibition of differentiation was dose dependent, with the concentration necessary for half-block similar to the $\mathrm{IC}_{50}$ values to block potassium channels. These results suggest that insulin increases the density of $\mathrm{K}_{\mathrm{v}}$ and that these channels may be necessary for the normal growth of white adipocytes in culture.

Journal of Endocrinology (2002) 174, 299-307

\section{Introduction}

White adipose tissue is the major energy reserve in higher eukaryotes, primary purposes of which are the storage of triacylglycerol in periods of energy excess and its mobilization during energy deprivation. Recently, there has been a dramatic increase in the incidence of obesity resulting from an excess of white adipose tissue. This obesity may occur as a result of the enlargement of existing adipocytes and/or as a consequence of an increase in new fat cells. Although multiple factors modulate proliferation and differentiation of adipocytes (for reviews see Gregoire et al. 1998 and Boone et al. 2000), it is known that some hormones and growth factors act via specific receptors to transduce external growth and differentiation signals through a cascade of intracellular events. Insulin is able to stimulate cell proliferation in white adipose tissue (Géloën et al. 1989, Kras et al. 1999) and increases the number of differentiated cells for most primary preadipocytes (Gaben-Cogneville et al. 1990, Serrero \& Lepak 1999); few cells containing lipids can be observed in the absence of insulin.

Experiments with other cell types have implicated potassium channels as being essential for their proliferation and differentiation (Woodfork et al. 1995, Lepple-Wienhues et al. 1996, Skryma et al. 1997, Wang et al. 1997, Rouzaire-Dubois \& Dubois 1998, Vaur et al. 1998, Ghiani et al. 1999, Miki et al. 2001; for review see Rane 1999). It has been demonstrated that functional voltage-gated potassium channels may be necessary for the normal proliferation and differentiation of brown fat cells in culture (Pappone \& Ortiz-Miranda 1993) and that the purinergic modulations of these potassium currents may be important for altering adipocyte growth and development (Wilson \& Pappone 1999, Wilson et al. 1999). Brown fat tissue is important for maintaining body temperature and energy balance in mammals through its ability rapidly to convert metabolic energy into heat in response to sympathetic adrenergic stimulation (for review see Horwitz 1989). Environmental factors, such as exposure to cold or an unbalanced diet, produce an increase in both the amount of brown fat tissue and in heat production per cell. Although the regulating factors are complex, the major trophic stimulus seems to be the level of adrenergic stimulation sustained in the tissue mediated by noradrenaline. Thus proliferation and differentiation of brown fat cells is hormonally regulated, and the activity of voltagedependent potassium channels is necessary for the process.

In white adipocytes, obtained by culturing preadipocytes from rat epididymal tissue, we demonstrated the existence of voltage-dependent $\mathrm{K}^{+}$channels $\left(\mathrm{K}_{\mathrm{v}}\right)$ using the whole-cell variant of the patch-clamp technique 
(Ramírez-Ponce et al. 1996). These results were corroborated by other authors in isolated white adipocytes (Lee \& Pappone 1997, Ringer et al. 2000). In a preliminary study carried out by means of intracellular recording, we showed that insulin produced an average hyperpolarization of $13.5 \mathrm{mV}$ in resting potential, and increased the recovery time of membrane potential at the end of a hyperpolarization current pulse (Ramírez-Ponce et al. 1991). These results suggested that insulin could modulate $\mathrm{K}^{+}$conductances in white adipocytes. In this paper we tested the role of $\mathrm{K}_{\mathrm{v}}$ in adipogenesis by studying potassium currents in white adipocytes, obtained by culturing preadipocytes from the epididymal adipose tissue of rats, both with insulin $\left(\mathrm{WA}_{\mathrm{i}}\right)$ and without insulin $\left(\mathrm{WA}_{\mathrm{o}}\right)$. We present evidence that insulin increases the density of $\mathrm{K}_{\mathrm{v}}$ in white adipocytes, and that these channels may play a significant role in the differentiation process of such cells.

\section{Materials and Methods}

\section{Cell culture}

Preadipocytes from rat epididymal fat pads were isolated by means of incubation for $40 \mathrm{~min}$ at $37^{\circ} \mathrm{C}$ in the presence of collagenase as described previously (Ramírez-Ponce et al. 1996). The floating cells were suspended in a culture medium consisting of DMEM, supplemented with $10 \%$ neonatal calf serum, $2 \mathrm{mM}$ glutamine, $100 \mathrm{U} / \mathrm{ml}$ penicillin and $100 \mu \mathrm{g} / \mathrm{ml}$ streptomycin, and plated, in equal quantities, either onto polylysine-treated glass cover-slips for patch-clamp experiments or grid-embossed 35-mm tissue culture dishes for cell growth experiments. The insulin used for growth cells was biosynthetic human insulin, added to give a final concentration of $100 \mu \mathrm{U} / \mathrm{ml}$. In every case the cells were fed every third day. For electrophysiological studies, the cells were used between the 5 th and 12 th days of incubation.

\section{Patch-clamp experiments}

Ionic currents were recorded using the whole-cell configuration of the patch-clamp technique (Hamill et al. 1981), with an EPC-7 patch-clamp amplifier (List Electronics, Darmstadt, Germany). Data acquisition was performed by an ITC-16 computer interface (Instrutech Corp. Great Neck, NY, USA) and (Pulse+Pulsefit) software (Heka electronik, Lambrecht, Germany). Linear leak currents, through membrane capacitance, were cancelled on-line using $\mathrm{P} / 4$ procedure (Armstrong \& Bezanilla 1974).

The composition of the external control solution was $135 \mathrm{mM} \mathrm{NaCl}, 2 \cdot 7 \mathrm{mM} \mathrm{KCl}, 2.5 \mathrm{mM} \mathrm{CaCl} 2,1 \mathrm{mM}$ $\mathrm{MgCl}_{2}, 10 \mathrm{mM}$ Hepes and $5 \mathrm{mM}$ glucose; $\mathrm{pH}$ was adjusted to $7.35 \pm 0.02$ in all cases. To record tail currents, $\mathrm{NaCl}$ was replaced equimolarly with $\mathrm{KCl}$. In experiments where tetrethylammonium (TEA) was used, the external solution contained (in $\mathrm{mM}$ ): $80 \mathrm{NaCl}, 2.7 \mathrm{KCl} 1 \mathrm{CaCl}_{2}$, 70 Trizma, 5 glucose and, depending on the experiment, $0 \cdot 25,5$ and 50 TEA. The standard solution used to fill the electro-pipettes contained $80 \mathrm{mM}$ potassium glutamate, $20 \mathrm{mM}$ KF, $35 \mathrm{mM} \mathrm{KCl}, 2 \mathrm{mM} \mathrm{MgCl}, 10 \mathrm{mM}$ Hepes and $5 \mathrm{mM}$ EGTA; $\mathrm{pH}$ was adjusted to $7 \cdot 25-7 \cdot 30$.

\section{Cell growth}

Five squares of the grid with an appropriate number of cells were selected from each dish and photographed at 24-h intervals thereafter by a digital camera, Olympus DP-10 (Olympus Optical, Co., Hamburg, Germany) attached to the microscope. The images were transferred to a computer to be processed by the program Olympus $\mathrm{Dp}$-Soft. The procedure used to discriminate between undifferentiated and differentiated cells was based on their morphological differences, the main parameter being the content of lipid vacuoles. The preadipocytes have no or very small vacuoles and the mature adipocytes have easily observed spherical vacuoles. The counting of cells was carried out by the program, after pointing and marking them with the mouse. Immediately after the first count, the potassium channel blocker, TEA, was added to the culture media from a stock solution in water. Each experimental set always included a control group, which was grown and counted in parallel. The proliferation rates shown are normalized to the average value obtained by measuring samples from each set of dishes on day 1, before TEA was added to the cultures. The initial number of cells counted was in the range of 30-50 and was comparable for both control and treated cultures in order to avoid the possibility that changes in the number of differentiated cells were a consequence of changes in the initial cell numbers rather than as a result of the experimental manipulations.

\section{Data analysis}

The ionic currents registered were exported as ASCII files from Heka Pulse Software to be analysed and plotted by the graphic and data analysis program Microcal Origin 5.0 (Microcal Software, Inc. Northampton, MA, USA). The statistical test used was the analysis of variance, one-way ANOVA, supported by Microcal Origin 5.0, which determines whether the data means differ significantly.

\section{Results}

\section{Cell culture}

The cultures contained a variable mixture of mature white fat cells, preadipocytes and groups of tightly arranged cells (islets), which copurify with the free-floating fat cells, as 


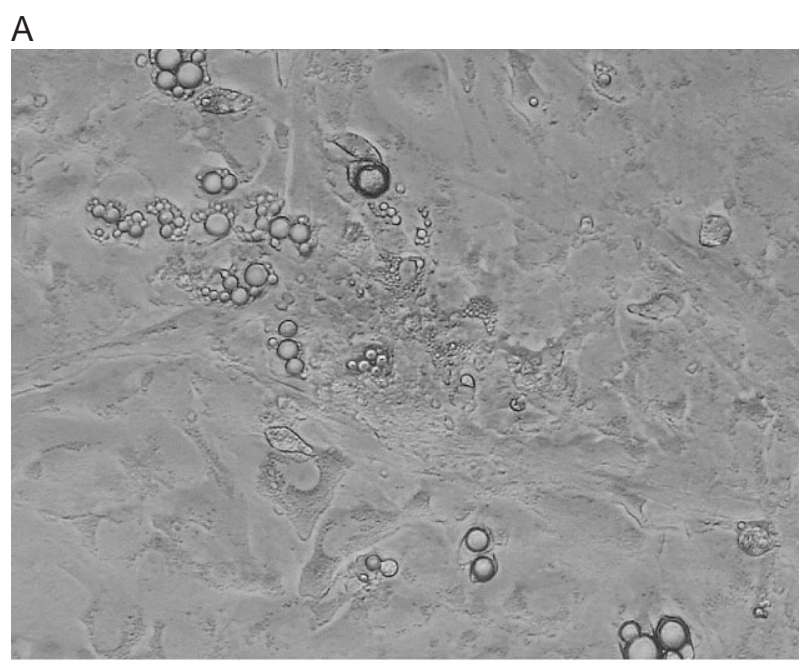

BM

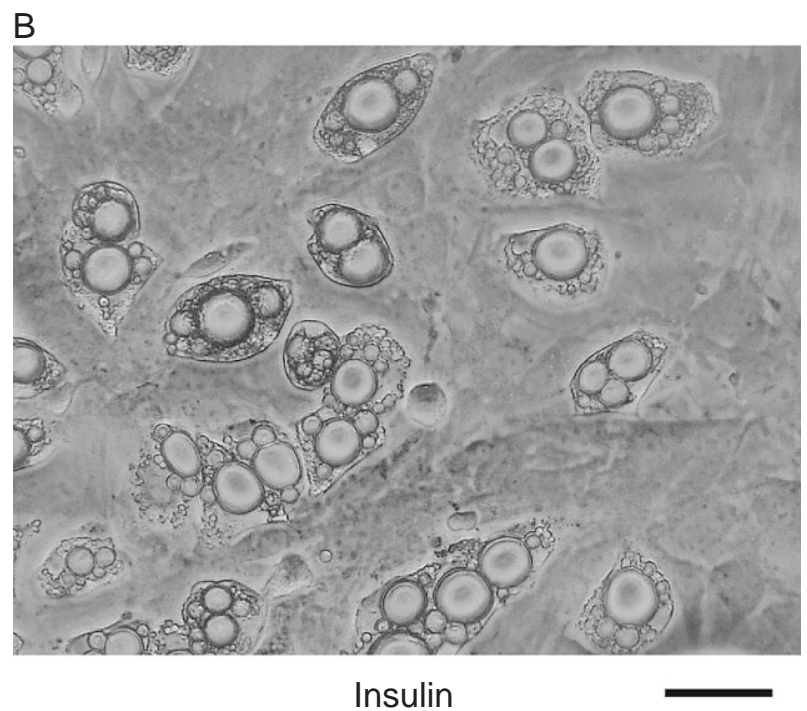

Figure 1 Cells cultured from the same white fat cell isolation after 7 days in basal medium (BM; $A$ ), and in the presence of $100 \mu \mathrm{U} / \mathrm{ml}$ insulin (B). Scale bar represents $50 \mu \mathrm{m}$.

described by Carraro et al. (1990). When cultured along with mature white adipocytes, the islets give rise to cells, initially fibroblast-like, which proliferate rapidly, acquire lipid droplets and transform into white adipocytes within 4-6 days without the addition of insulin to the medium (basal medium, BM). Figure 1A shows a culture with mature adipocytes grown in BM. Isolated mature adipocytes added to the culture medium demonstrated differentiation-promoting activity, suggesting a paracrine effect of these cells (Carraro et al. 1990, Considine et al. 1996). In vivo, islets may constitute a source of newly formed adipocytes in the adult rat. The differentiation of these potential adipocytes may be regulated, at least in part, by the mature fat cells via the paracrine effect. The time necessary to obtain mature adipocytes is reduced and the size of cells larger when insulin is added to the culture medium, as is shown in Fig. 1B. In the same culture time, the number of differentiated cells increased by $73.5 \% \pm 11.8$ in the presence of insulin (average value from measurements in 10 cultures \pm S.E.).

\section{Effect of insulin treatment on $\mathrm{K}^{+}$currents of white adipocytes}

The macroscopic membrane currents of white adipocytes were studied using the whole-cell variant of the patchclamp technique. Occasionally, very small currents were registered in fibroblastic cells which had not accumulated lipid granules or whose content was very slight (preadipocytes) (Fig. 2A), and there were no differences between the small current obtained in cells from cultures treated with or without insulin. Nevertheless, all differentiated cells grown in $\mathrm{BM}, \mathrm{WA}_{\mathrm{o}}$, showed the same outward currents which exhibited a sigmoidal activation time course (Fig. 2B). We have previously described these currents in white adipocytes in detail and demonstrated the existence of voltage-dependent $\mathrm{K}^{+}$channels in these cells (Ramírez-Ponce et al. 1996). Lee \& Pappone (1997) and Ringer et al. (2000) have described identical channels in isolated adipocytes, the latter by using single channel recording in outside-out configuration. These currents correspond to voltage-dependent $\mathrm{K}^{+}$-channels (delayed rectifier). Currents obtained in $\mathrm{WA}_{\mathrm{i}}$ had higher values than those obtained in $\mathrm{WA}_{\mathrm{o}}$ (Fig. 2C). Figure 2D shows the peak current-voltage relation between the two cells of traces $\mathrm{B}$ and $\mathrm{C}$. The threshold for current activation in both cells was similar, around $-20 \mathrm{mV}$. There were no apparent differences in voltage dependence in the currents in cells from diverse cultures with or without insulin. Figure 3(A-D) shows the kinetics of the currents. Figure $3 \mathrm{~A}$ shows the traces that were obtained as an average of currents recorded from 41 cells grown in BM and 39 cells grown with insulin. In Fig. 3B it can be seen that, when these currents were scaled, there were no significant differences in their activation and inactivation kinetics. Figure $3 \mathrm{C}$ presents tail currents obtained as an average of currents recorded from 7 and 8 cells grown in $\mathrm{BM}$ or with insulin respectively. Figure $3 \mathrm{D}$ shows that sections scaled corresponding to tail currents recorded in 3C do not present significant differences in their closing kinetics. Moreover, we found no evidence of any other type of voltage-gated channel. In particular, there was no indication of an inward current that could reveal the presence of significant voltage-gate $\mathrm{Na}^{+}$or $\mathrm{Ca}^{2+}$ conductances. To verify whether differences in the recorded current amplitude might be related to different cellular size, we calculated the current density $\left(\mathrm{pA} / \mu \mathrm{m}^{2}\right)$ of each registered cell. The area was calculated taking into account the spherical or ellipsoidal shape of the cells, measuring their diameters with the millimetered ocular of the 

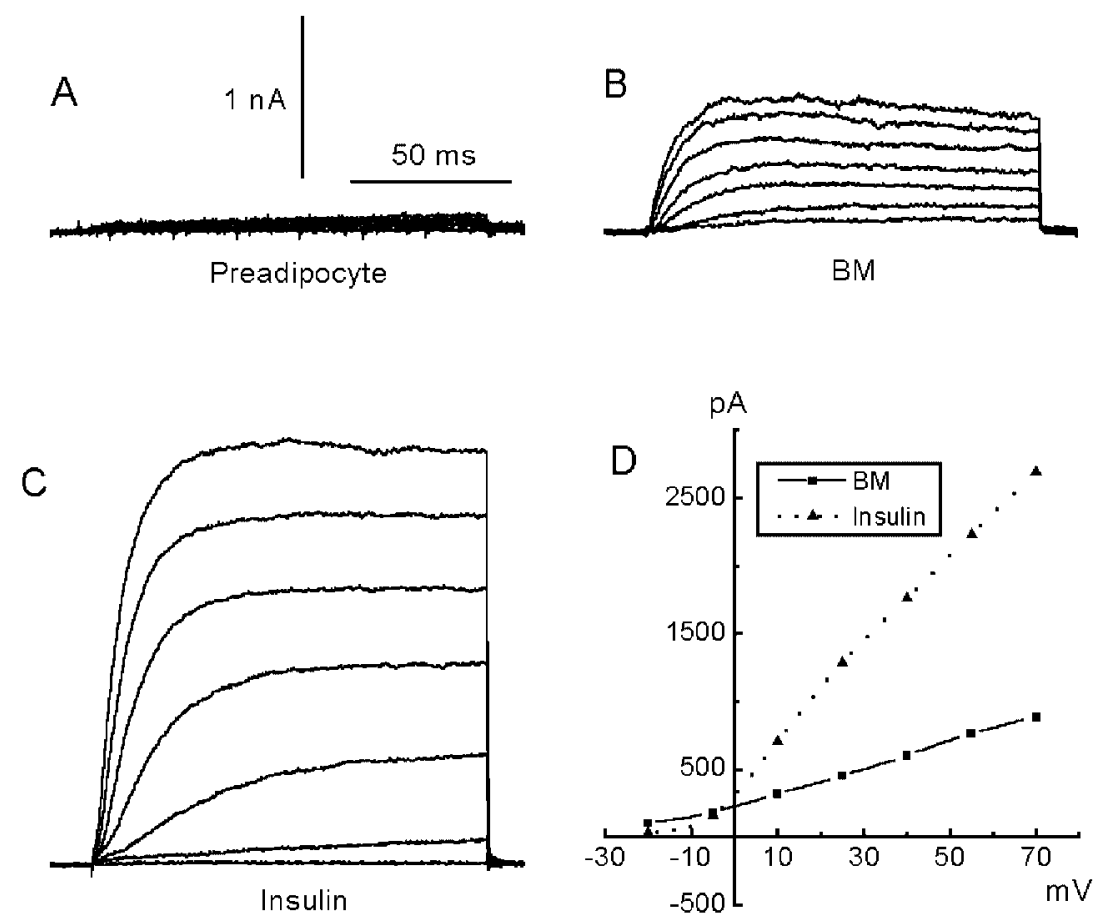

Figure 2 lonic currents from preadipocyte (A) and white adipose cells obtained in BM (B) or in the presence of $100 \mu \mathrm{U} / \mathrm{ml}$ insulin (C). The current traces in $\mathrm{A}-\mathrm{C}$ are superimposed and recorded every $8 \mathrm{~s}$ for $125 \mathrm{~ms}$ voltage steps in $15 \mathrm{mV}$ increments from -20 to $+70 \mathrm{mV}$, applied from a holding potential of $-70 \mathrm{mV}$. External and internal solutions were used as described in Materials and Methods. (D) Current-voltage relationship obtained by measuring the peak amplitude of the traces shown in panels $\mathrm{B}$ and $\mathrm{C}$.

microscope. The mean value of the current densities of preadipocytes, $\mathrm{WA}_{\mathrm{o}}$ and $\mathrm{WA}_{\mathrm{i}}$ cells are significantly different at the $10^{-6}$ level $\left(P=2.489 \times 10^{-7}\right)$, as shown in Table 1. On the assumption that current density is proportional to channel density, these differences may suggest that white adipocytes modulate potassium channel density according to their state of proliferation and that insulin increases the incorporation of channels in differentiated adipocytes.

Our previous work showed that voltage-dependent ionic potassium current $\left(\mathrm{I}_{\mathrm{K}, \mathrm{V}}\right)$ can be blocked by approximately $64 \%$ by millimolar concentrations of TEA $(5 \mathrm{mM})$, and recovered to $94 \%$ of the control level when the TEA was washed from the bath (Ramírez-Ponce et al. 1996). In this experiment, we tested the sensitivity of $\mathrm{I}_{\mathrm{K}, \mathrm{V}}$ to different concentrations of TEA. Figure 4A shows that external TEA $(50 \mathrm{mM})$ blocked the current by approximately $92 \cdot 66 \%(n=9)$. The current recovered to $75 \%$ of the control level when the TEA was washed from the bath. The TEA dose-response relationship for blocking the current peak using this agent is shown in Fig. 4B. The $\mathrm{IC}_{50}$ values and Hill coefficient of TEA inhibition of $\mathrm{I}_{\mathrm{K}, \mathrm{V}}$ were determined by a least-squares fit of the $\log [\mathrm{I} /(1-\mathrm{I})]$ versus $\log$ [TEA], where $I$ is the percentage inhibition of current in the presence of TEA. The I value was deter- mined from peak currents with the blocker relative to control currents during depolarisation to $+70 \mathrm{mV}$. This yielded $\mathrm{IC}_{50}$ values of 1.08 and $2.35 \mathrm{mM}$ and Hill coefficients of 0.63 and 0.82 obtained for $\mathrm{WA}_{\mathrm{o}}$ and $\mathrm{WA}_{\mathrm{i}}$ respectively. These values are similar to those obtained in mature adipocytes with single channels recording in outside-out configuration (Ringer et al. 2000).

Effect of insulin and TEA treatment on the growth and development of white adipocytes

Cells were plated on plastic grid-labelled culture dishes, enabling us to recognize identical areas of the dish for counting cells each day. The total number of cells (preadipocytes and mature adipocytes) in BM cultures increased approximately $2 \cdot 5$-fold in 4 days (Fig. 5A). The rate of proliferation of cells was the same in cultures grown with 0.25 or $5 \mathrm{mM}$ TEA. However, with $50 \mathrm{mM}$ TEA (almost completely blocking the potassium current), cell proliferation was blocked. In cultures exposed to insulin, the total cells counted increased approximately $2 \cdot 5$-fold in 3 days. Likewise, in these conditions the presence of $0 \cdot 25$ to $5 \mathrm{mM}$ TEA did not affect the proliferation of the cells, although proliferation was affected with $50 \mathrm{mM}$ TEA. 


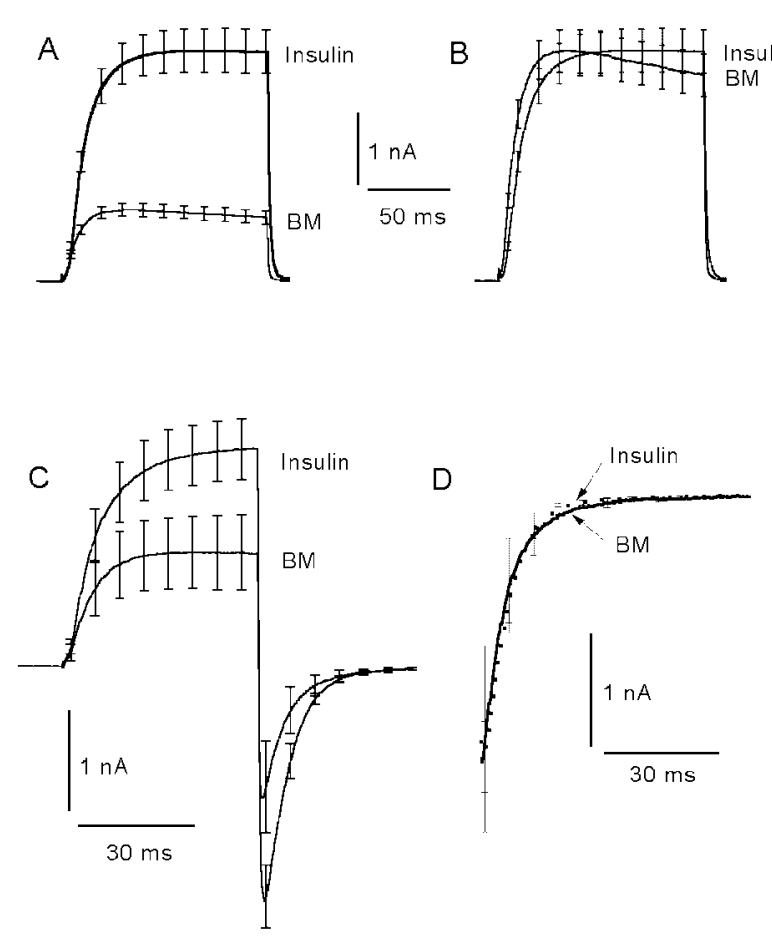

Figure 3 (A-D) Kinetic analysis of ionic currents from white adipose cells obtained in BM or in the presence of $100 \mu \mathrm{U} / \mathrm{ml}$ insulin. The current traces in A are recorded for $125 \mathrm{~ms}$ voltage pulses from -20 to $+70 \mathrm{mV}$ applied from a holding potential of $-70 \mathrm{mV}$. Panel (B) shows the same ionic currents scaled. External and internal solutions were used as described in Materials and Methods. (C) Current records with external $135 \mathrm{mM} \mathrm{K}^{+}$; tail currents were recorded during $60 \mathrm{~ms}$ voltage pulses to $-90 \mathrm{mV}$ after a pulse to $60 \mathrm{mV}$ of $50 \mathrm{~ms}$ duration applied from a holding potential of $-70 \mathrm{mV}$. Panel (D) shows the same tail currents scaled. Internal solutions were used as described in Materials and Methods.

TEA also blocked cellular differentiation which has concentration dependence, but at different magnitudes to that for cell proliferation. Differentiation, unlike proliferation, was affected by concentrations of TEA of between 0.25 and $5 \mathrm{mM}$. Figure 6 shows that cultures with $5 \mathrm{mM}$ TEA lack mature adipocytes. The effect of TEA is more evident in cultures exposed to BM. In the presence of

Table 1 The area and current density of preadipocytes and of adipocytes grown in basal medium without or with the addition of insulin. Results are means \pm S.E.M. The numbers in parentheses correspond to the total number of cells selected

\begin{tabular}{|c|c|c|}
\hline & $\begin{array}{l}\text { Area } \\
\left(\mu \mathrm{m}^{2}\right)\end{array}$ & $\begin{array}{l}\text { Density of current }{ }^{* *} \\
\left(\mathrm{pA} / \mu \mathrm{m}^{2}\right)\end{array}$ \\
\hline Preadipocyte $(n=6)$ & $846 \pm 177$ & $0 \cdot 185 \pm 0 \cdot 053$ \\
\hline $\mathrm{BM}(n=55)$ & $1119 \pm 301$ & $0 \cdot 620 \pm 0.039$ \\
\hline Insulin $(n=47)$ & $3532 \pm 355$ & $1 \cdot 148 \pm 0 \cdot 098$ \\
\hline
\end{tabular}

${ }^{*} P<10^{-6}$ (one-way-ANOVA. Microcal Origin 5.0).
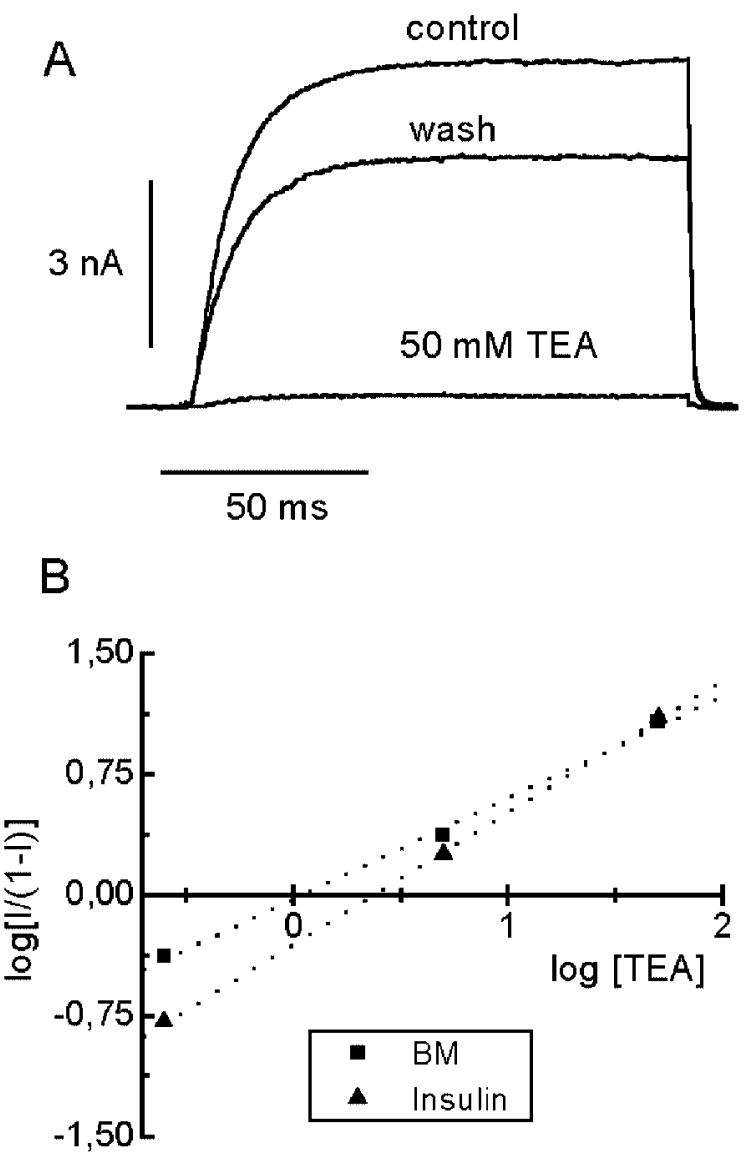

Figure 4 ( $A$ and $B$ ) Effects of TEA on potassium currents. (A) lonic currents from a cell, grown with $100 \mu \mathrm{U} / \mathrm{ml}$ insulin, during a $125 \mathrm{~ms}$ voltage pulse from -70 to $+70 \mathrm{mV}$, applied from a holding potential of $-70 \mathrm{mV}$, in control solutions, with $50 \mathrm{mM}$ TEA, and after washing TEA from the bath. The internal solution is as described in Materials and Methods. (B) Dose-response relationship for blocking potassium currents in cells differentiated in BM ( $\mathbf{\square})$, and in the presence of insulin ( $\boldsymbol{\Delta})$; percentage inhibition, I, was determined from peak currents with the blocker relative to control currents during depolarization to $+70 \mathrm{mV}$. Each symbol represents the average value from measurements in 6-10 cells. The data were fitted to the Hill equation. $I C_{50}$ values of $1 \cdot 08$ and $2.35 \mathrm{mM}$ and Hill coefficients of 0.63 and 0.82 were obtained for adipose tissue without $\left(\mathrm{WA}_{\mathrm{o}}\right)$ and with $\left(\mathrm{WA}_{\mathrm{i}}\right)$ insulin respectively.

insulin this effect is less pronounced, and, at $5 \mathrm{mM}$ TEA, some differentiated adipocytes can be observed. Table 2 shows the average inhibition of differentiation by TEA in 6 cultures taken on day 8 after isolation. The proportion of differentiated cells was calculated in each square of the grid as the ratio between the number of mature cells (cells with a high content of lipid droplets) relative to the total number of cells in the same square. Percentage inhibition was determined as the ratio of the number of differentiated cells in the blocker and control respectively. Figure 7 shows the data of Table 2 fitted to the Hill equation, 


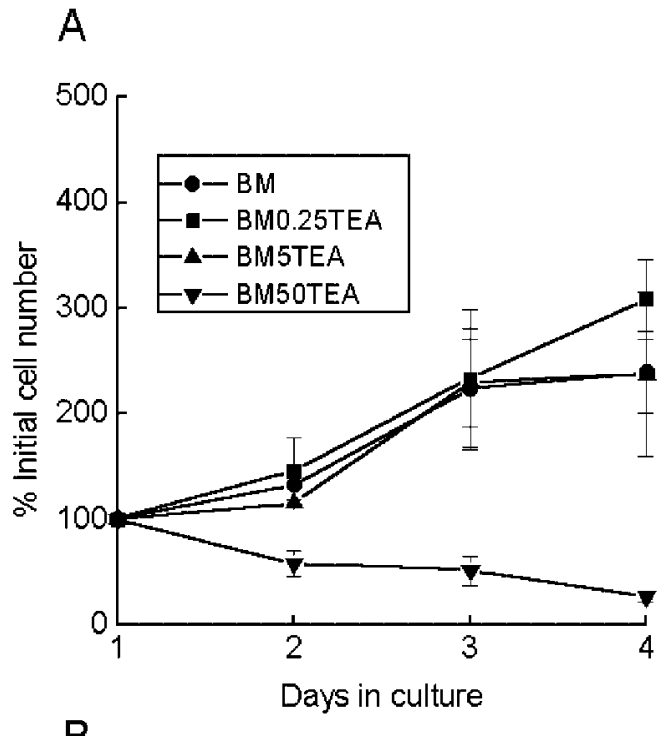

B

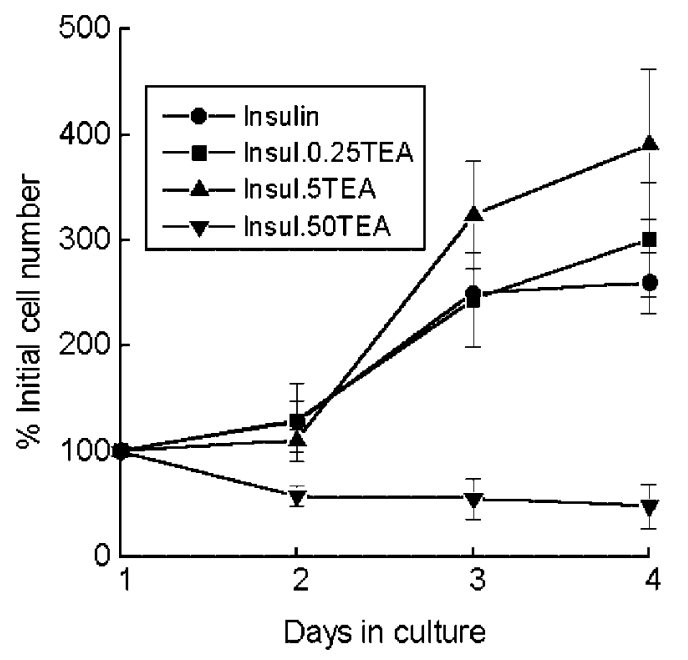

Figure 5 Number of cells as a function of time in culture. All data are normalized to the initial number. Each symbol represents the average value from measurements in 6 cultures \pm S.E. (where larger than the symbol). (A and B) Continuous presence of $0.25(\boldsymbol{\square})$ or $5(\boldsymbol{\Delta}) \mathrm{mM}$ TEA did not affect the rate of cell proliferation compared with parallel control cultures $(\mathbf{O})$ in BM or insulin, but $50 \mathrm{mM}$ TEA blocked proliferation $(\boldsymbol{\nabla})$ independent of the presence of insulin.

where $\mathrm{I}$ is the percentage inhibition of cell differentiation in the presence of TEA. The values of $\mathrm{IC}_{50}$ for blocking cell differentiation $(1.02$ and $2.4 \mathrm{mM}$, in cells grown in $\mathrm{BM}$ or with insulin respectively) are similar to the ability of the drug to block voltage-dependent potassium channels, as shown in Fig. 4B, and are consistent with the hypothesis that the inhibition of cell differentiation is dependent on blocking the potassium channels. These results suggest that functional voltage-dependent potassium channels may be necessary for the normal development of white adipose cells in culture.

\section{Discussion}

The results presented here indicate that insulin increases the density of voltage-dependent potassium channels in white adipocytes and that these channels may be involved in the process of adipogenesis. Insulin is a hormone known to act on the proliferation and differentiation process in white adipocytes, in addition to its role in the metabolic activity of these cells. In this study, we have verified that cells proliferate and differentiate quickly in the presence of insulin, reaching a larger size than in cells grown without insulin. Recordings of macroscopic membrane ionic currents demonstrate that $\mathrm{I}_{\mathrm{K}, \mathrm{V}}$ was present in all differentiated cells with the same characteristics, and occasionally in preadipocytes. Nevertheless, $\mathrm{K}^{+}$currents recorded in differentiated cells in the presence of insulin were higher, as was the density current. Experiments with other cell types have also shown a change in $\mathrm{K}^{+}$current density between the subpopulations obtained throughout their differentiation process (Lee et al. 2001). The results presented in this paper confirm a preliminary study made using intracellular recordings, which showed that insulin modifies the electrical properties of white adipocytes, hence possibly modulating $\mathrm{K}^{+}$conductances in these cells (Ramírez-Ponce et al. 1991).

Our data show that $\mathrm{I}_{\mathrm{K}, \mathrm{V}}$ can be blocked by millimolar concentrations of TEA, with $\mathrm{IC}_{50}$ values of 1.08 and $2.35 \mathrm{mM}$ for cells grown in BM and insulin respectively, in accordance with the larger number of $\mathrm{K}^{+}$channels in cells differentiated with insulin. We tested whether potassium channels were involved in the growth of white adipocytes by adding millimolar concentrations of TEA to the culture medium. In all cultures it was necessary to add very high doses of TEA $(50 \mathrm{mM})$ to block cellular proliferation. On the other hand, we found that mature white adipocytes differentiated in culture were blocked by a lower concentration of TEA, and with similar dosedependence to the blocking of $\mathrm{I}_{\mathrm{K}, \mathrm{V}}$. On the assumption that this agent, in concentrations where it has no effect on cellular proliferation $(5 \mathrm{mM})$, does not have unanticipated effects on other cell systems implicated in cellular differentiation, our results would indicate that expression of functional potassium channels are necessary for the development of white adipocytes in culture, in addition to other factors previously described (for reviews see Gregoire et al. 1998 and Boone et al. 2000). These results add to the growing list of cell types in which potassium channels have been implicated in cellular growth. In brown fat cells, functional voltage-gated $\mathrm{K}^{+}$channels may be necessary for their proliferation and differentiation (Pappone \& Ortiz-Miranda 1993), and purinergic modulation of $\mathrm{I}_{\mathrm{K}, \mathrm{V}}$ may be important for altering adipocyte growth and 
A
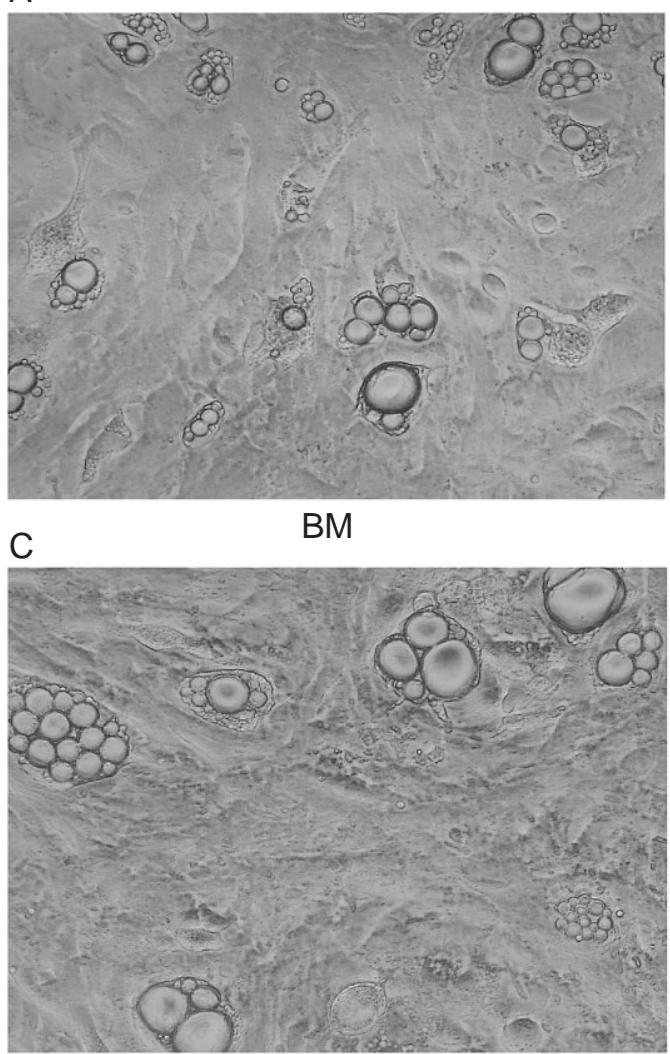

Insulin
B

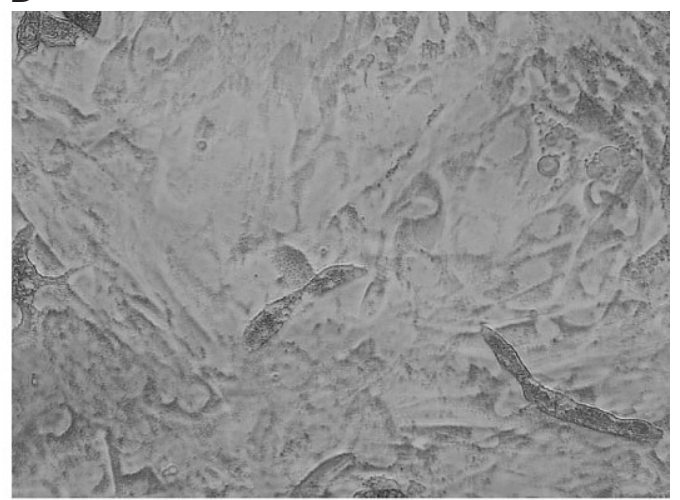

$\mathrm{BM}+5 \mathrm{mM}$ TEA

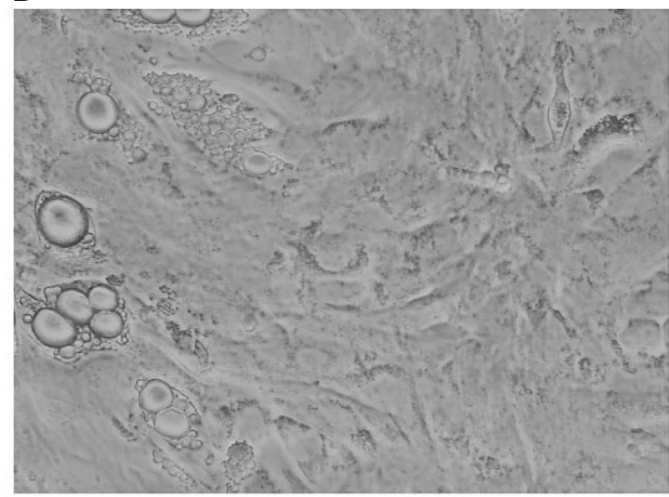

Insulin + 5mM TEA

Figure 6 Cultured cells from the same white fat cell isolation. Each panel was taken on day 10 after isolation. Cells were grown in $B M(A), B M+5 m M$ TEA (B), insulin (C), and insulin $5 \mathrm{mM}$ TEA (D). Note that differentiation of white adipocytes ceases in (B), and diminishes in (D). Scale bar represents $50 \mu \mathrm{m}$.

development (Wilson \& Pappone 1999, Wilson et al. 1999).

Noradrenaline (NA) is another hormone known to act on the metabolic activity of white adipose tissue, promoting the release of free fatty acids from these cells. There are studies which indicate that NA inhibits preadipocyte proliferation in rats, and that it may, therefore, be an important negative regulatory component of adipocyte growth (Jones et al. 1992). In previous studies we demonstrated that NA may modulate $\mathrm{K}^{+}$conductances by blocking them and causing white adipocytes to

Table 2 Percentage inhibition of differentiation by TEA. Results are means \pm S.E.M

\begin{tabular}{|c|c|c|}
\hline \multicolumn{3}{|c|}{ Basal medium } \\
\hline TEA $(n$ & & \\
\hline $0 \cdot 25$ & $20 \cdot 69 \pm 0 \cdot 29$ & $3 \cdot 0 \pm 2 \cdot 50$ \\
\hline 5 & $69 \cdot 27 \pm 7 \cdot 77$ & $49 \cdot 25 \pm 15 \cdot 95$ \\
\hline 50 & $99 \cdot 80 \pm 0 \cdot 1$ & $99 \cdot 80 \pm 0 \cdot 2$ \\
\hline
\end{tabular}

depolarize (Ramírez-Ponce et al. 1991), and that this modulator effect might be mediated by cAMP (Ramírez-Ponce et al. 1998). The effects described for NA and insulin on the electrical activity of white adipocytes and their relationship to cellular growth could be explained in a similar way. The lipolytic action of NA increases the concentration of cAMP. An increase in this intracellular mediator would be responsible for the partial blocking of $\mathrm{K}^{+}$conductances and cause the cells to depolarize. Furthermore, increases of cAMP would reduce the expression of $\mathrm{K}^{+}$channels in preadipocytes and diminish the differentiation of these cells. Contradictory results have been obtained in studies which address the question of whether cAMP stimulates or inhibits adipose conversion (Boone et al. 1999), thereby suggesting different regulatory mechanisms between species. There are examples of other tissues in which an increase of cAMP reduces outward $\mathrm{K}^{+}$current amplitude by acting at the translational level to destabilize $\mathrm{Kv} 1 \cdot 1 \mathrm{mRNA}$ (Allen et al. 1998). On the other hand, the antilipolytic action of insulin reduces the concentrations of cAMP; this, in turn, 


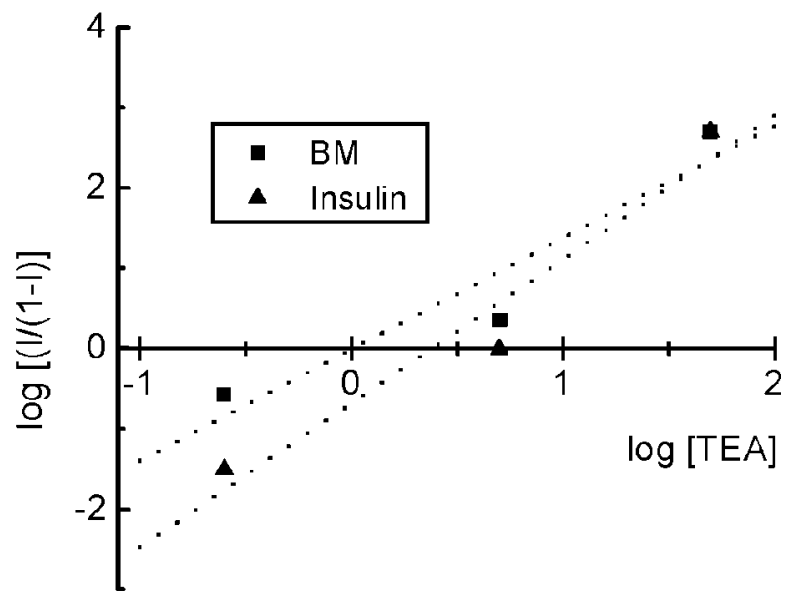

Figure 7 Dose-response relationship for inhibition of differentiation by TEA of the white adipose cell in BM $(\mathbf{\square})$, and in the presence of insulin $(\boldsymbol{\Delta})$. Percentage inhibition was determined as the ratio of the proportion of differentiated cells (cells with a high content of lipid droplets) in the blocker relative to the proportion of differentiated cells in the control. Each symbol represents the average value from measurements in 6 cultures taken on day 8 after isolation. The data were fitted to the Hill equation. $\mathrm{IC}_{50}$ values of 1.02 and $2.4 \mathrm{mM}$ and Hill coefficients of 1.39 and 1.79 were obtained for $\mathrm{WA}_{o}$ and $\mathrm{WA}_{i}$ respectively.

activates $\mathrm{K}^{+}$conductances, which would explain the hyperpolarization observed in white adipocytes after the addition of insulin (Ramírez-Ponce et al. 1991). A decrease in cAMP could increase the expression of $\mathrm{K}^{+}$ channels.

The present results suggest that $\mathrm{K}^{+}$channels could play a significant role in the development of white adipocytes, although further studies would be necessary to establish it definitively.

\section{Acknowledgements}

This work was partially supported by grants from DGICYT (PB96-1332) and Junta de Andalucía (CVI-236).

\section{References}

Allen ML, Koh DS \& Tempel BL 1998 Cyclic AMP regulates potassium channel expression in C6 glioma by destabilizing Kv1.1 mRNA. PNAS 95 7693-7698.

Armstrong CM \& Bezanilla F 1974 Charge movement associated with the opening and closing of the activation gates of the $\mathrm{Na}$ channels. Journal of General Physiology 63 533-552.

Boone C, Gregoire F \& Remacle C 1999 Various stimulators of the cyclic AMP pathway fail to promote adipose conversion of porcine preadipocytes in primary culture. Differentiation 64 255-262.

Boone C, Mourot J, Grégoire F \& Remacle C 2000 The adipose conversion process: regulation by extracellular and intracellular factors. Reproduction Nutrition Development 40 325-358.
Carraro R, Lu Z, Li ZH, Johnson JE Jr \& Gregerman RI 1990 Adipose tissue islets: tissue culture of a potential source of fat cells in the adult rat. FASEB Journal 4 201-207.

Considine RV, Nyce MR, Morales LM, Magosin SA, Sinha MK, Bahuer TL, Rosato EL, Golberg J \& Caro JF 1996 Paracrine stimulation of preadipocyte-enriched cell cultures by mature adipocytes. American Journal of Physiology 270 E895-E899.

Gaben-Cogneville AM, Breant B, Coundray AM, Hoa DH \& Mester J 1990 Differentiation of newborn rat preadipocytes in culture: effects of insulin and dexamethasone. Experimental Cell Research 191 133-140.

Géloën A, Collet AJ, Guay G \& Bukowiecki LJ 1989 Insulin stimulates in vivo cell proliferation in white adipose tissue. American Journal of Physiology 256 C190-C196.

Ghiani CA, Yuan X, Eisen AM, Knutson PL, DePinho RA, McBain CJ \& Gallo V 1999 Voltage-activated $\mathrm{K}^{+}$channels and membrane depolarization regulate accumulation of the cyclin-dependent kinase inhibitors p27 (Kip1) and p21 (CIP1) in glial progenitor cells. Journal of Neuroscience 19 5380-5392.

Gregoire FM, Smas CM \& Sul HS 1998 Understanding adipocyte differentiation. Physiological Review 78 783-809.

Hamill OP, Marty A, Neher E, Sakmann B \& Sigworth FJ 1981 Improved patch-clamp techniques for high-resolution current recording from cells and cell-free membrane patches. Pflügers Archiv $39185-100$.

Horwitz B 1989 Biochemical mechanisms and control of cold-induced cellular thermogenesis in placental mammals. In Advances in Comparative and Environmental Physiology, vol 4, pp 83-116. Ed. LCH Wang. Berlin: Springer-Verlag.

Jones DD, Ramsay TG, Hausman GJ \& Martin RJ 1992 Norepinephrine inhibits rat pre-adipocyte proliferation. International Journal of Obesity and Related Metabolic Disorders 16 349-354.

Kras KM, Hausman DB, Hausman GJ \& Martín RJ 1999 Adipocyte development is dependent upon stem cell recruitment and proliferation of preadipocytes. Obesity Research 7 491-497.

Lee KM, Ye GL, Yung WH, Leung KS \& Leung PC 2001 In situ model for studying currents in various growth plate chondrocyte subpopulations. Life Sciences 69 721-728.

Lee SC \& Pappone PA 1997 Membrane responses to extracellular ATP in rat isolated white adipocytes. Pflügers Archiv 434 422-428.

Lepple-Wienhues A, Berweck S, Böhming M, Leo CP, Meyling B, Garbe C \& Wiederholt M $1996 \mathrm{~K}^{+}$channels and the intracellular calcium signal in human melanoma cell proliferation. Journal of Membrane Biology 151 149-157.

Miki T, Iwanaga T, Nagashima K, Ihara Y \& Seino S 2001 Roles of ATP-sensitive $\mathrm{K}^{+}$channels in cell survival and differentiation in the endocrine pancreas. Diabetes 50 S48-S51.

Pappone PA \& Ortiz-Miranda SI 1993 Blockers of voltage-gated K channels inhibit proliferation of cultured brown fat cells. American Journal of Physiology 264 C1014-C1019.

Ramírez-Ponce MP, Acosta J \& Bellido J 1991 Effects of noradrenaline and insulin on electrical activity in white adipose tissue of rat. Revista Española de Fisiología 47 217-222.

Ramírez-Ponce MP, Mateos JC, Carrión N, \& Bellido JA 1996 Voltage-dependent potassium channels in white adipocytes. Biochemical and Biophysical Research Communications 223 250-256.

Ramírez-Ponce MP, Acosta J, Bellido J \& Mateos JC 1998 Noradrenaline modulates the electrical activity of white adipocytes by a cAMP-dependent mechanism. Journal of Endocrinology 159 397-402.

Rane SG 1999 Potassium channels as targets for modulating cell growth and differentiation. In Perspectives in Drug Discovery and Design, vol 15/16, pp 295-311. Netherlands: Kluwer Academic Publishers.

Ringer E, Russ U \& Siemen D $2000 \beta_{3}$-Adrenergic stimulation and insulin inhibition of non-selective cation channels in white adipocytes of the rat. Biochimica et Biophysica Acta 1463 241-253. 
Rouzaire-Dubois B \& Dubois JM $1998 \mathrm{~K}^{+}$channel block-induced mammalian neuroblastoma cell swelling: a possible mechanism to influence proliferation. Journal of Physiology 510 93-102.

Serrero G \& Lepak N 1999 Insulin but not IGF-I is required for the maintenance of the adipose phenotype in the adipogenic cell line 1246. In Vitro Cellular and Developmental Biology. Animal 35 642-646.

Skryma RN, Prevarskaya NB, Dufy-Barbe L, Odessa MF, Audin J \& Dufy B 1997 Potassium conductance in the androgen-sensitive prostate cancer cell line, LNCaP: involvement in cell proliferation. Prostate 33 112-122.

Vaur S, Bresson-Bepoldin L, Dufy B, Tuffet S \& Dufy-Barbe L 1998 Potassium channel inhibition reduces cell proliferation in the GH3 pituitary cell line. Journal of Cell Physiology 177 402-410.

Wang L, Xu B, White RE \& Lu L 1997 Growth factor-mediated K channel activity associated with human myeloblastic ML-1 cell proliferation. American Journal of Physiology 273 C1657-C1665.
Wilson SM \& Pappone PA 1999 P2 receptor modulation of voltagegated potassium currents in brown adipocytes. Journal of General Physiology 113 125-138.

Wilson SM, Barsoum MJ, Wilson BW \& Pappone PA 1999 Purine nucleotides modulate proliferation of brown fat preadipocytes. Cell Proliferation 32 131-140.

Woodfork KA, Wonderlin WF, Peterson VA \& Strobl JS 1995 Inhibition of ATP-sensitive potassium channels causes reversible cell-cycle arrest of human breast cancer cells in tissue culture. Journal of Cell Physiology 162 163-171.

Received in final form 29 April 2002 Accepted 21 May 2002 